\title{
LAT1-Targeting Thermoresponsive Liposomes for Effective Cellular Uptake by
} Cancer Cells

Minami Matsuura-Maekawa ${ }^{\dagger}$, Kei Fujieda ${ }^{\dagger}$, Yutaro Maekawa ${ }^{\dagger}$, Tomohiro Nishimura ${ }^{\dagger}$,

Kenichi Nagase ${ }^{\dagger}{ }^{\dagger}$ and Hideko Kanazawa ${ }^{\dagger}{ }^{\dagger}$

${ }^{\dagger}$ Faculty of Pharmacy, Keio University, 1-5-30, Shibakoen, Minato-ku, Tokyo 105-8512, Japan

* Correspondence: nagase-kn@pha.keio.ac.jp, kanazawa-hd@pha.keio.ac.jp; Tel.: +81-3-5400-1378 

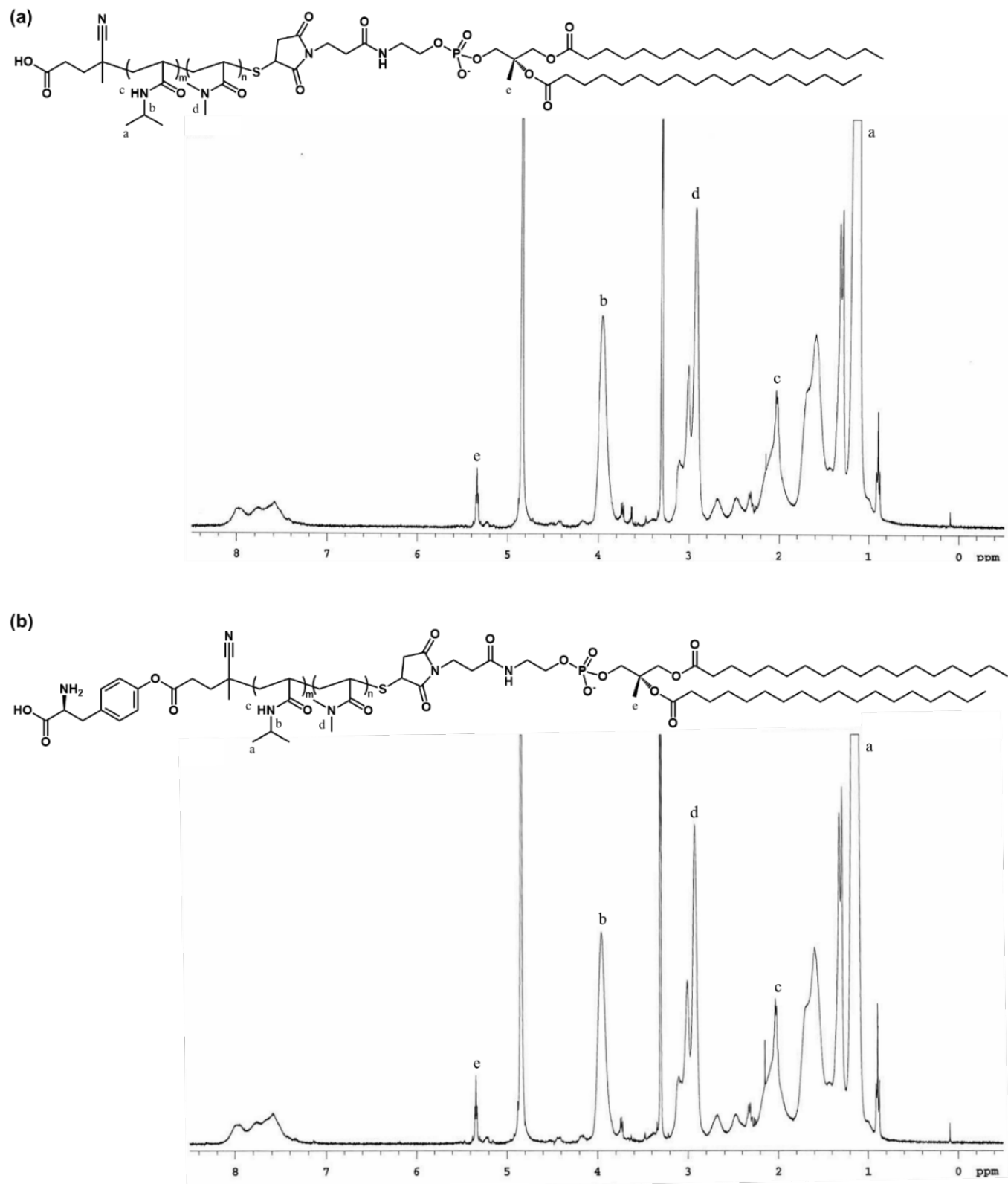

Figure S1. ${ }^{1} \mathrm{H}-\mathrm{NMR}$ of DOPE-modified thermoresponsive polymers (400 MHz, $\mathrm{CD}_{3} \mathrm{OD}$ ); (a) P(NIPAAmco-DMAAm)-DOPE: the integrated proton signals derived from NIPAAm methine (1H, $3.96 \mathrm{ppm})$, DMAAm methyl $(6 \mathrm{H}, 3.01 \mathrm{ppm})$, DOPE methine $(1 \mathrm{H}, 5.34 \mathrm{ppm})(\mathrm{b})$ P(NIPAAm-co-DMAAm20\%)DOPE: the integrated proton signals derived from NIPAAm methine $(1 \mathrm{H}, 3.96 \mathrm{ppm})$, DMAAm methyl (6H, $3.01 \mathrm{ppm})$, DOPE methine (1H, $5.34 \mathrm{ppm})$. 